\title{
Stakeholder expectations of the public in local coastal flood risk management in England
}

\author{
Sien van der Plank, University of Southampton, Southampton, United Kingdom \\ Sally Brown, University of Southampton, Southampton and Bournemouth University, \\ United Kingdom \\ Robert J. Nicholls, University of Southampton, Southampton, United Kingdom \\ Emma L. Tompkins, University of Southampton, Southampton, United Kingdom
}

\begin{abstract}
The flood risk management (FRM) doctrine that drives coastal flood preparedness in England acknowledges that not all floods can be prevented. Subsequently, beyond flood prevention other measures such as control, acceptance, adaptation, and redistribution constitute part of both national management policy and local policy implementation. The aim of this paper is to analyse the challenges of stakeholders implementing FRM policy locally, and their expectations of the public regarding coastal flood risk. We analyse the challenges from engineering, planning and insurance perspectives, through thematic analysis of semi-structured interviews in two case studies in contrasting English regions.
\end{abstract}

In the North West case study, covering parts of the Lancashire and Cumbrian coastlines, there is a contrast between the ongoing significant investment on the Fylde Peninsula (in 2015-2021, £120 million will be invested on coastal protection schemes) and the Cumbrian coastline, where a strategy is still being produced. In the South, an area composed of parts of the Dorset, Hampshire and the Isle of Wight coastlines was studied. Similarly to the North West, this area encompasses contrasting coastlines of significant settlements as well as more sparsely populated coast. Both cases have a legacy of coastal defences as well as more rural stretches of coastline with a defence legacy but less contemporary spending. Thus, it was possible to compare responses across stakeholder groups and case areas experiencing locally different environmental, social and economic conditions.

A set of 45 interviewees (stakeholders with involvement or interest in coastal flood risk in the North West or South coast) were questioned regarding the costs, timing, power, responsibility, acceptability, equity, and effectiveness of FRM. Responses were coded and analysed using thematic analysis.

Results suggest in the case study areas there is a disjuncture between the stakeholders' perceived need for increased public debate on a longer-term, more holistic vision for the coast, and a public who is considered to be largely unaware, uninvolved and not feeling responsible for coastal FRM. While the Environment Agency and Local Authorities have clear, local and regional FRM responsibilities through the Flood and Water Management Act 2010, the respondents in the North West and South case areas desire further devolution of these responsibilities to the household and the individual. Simultaneously, they perceive the public to be currently unaware of their flood risk and not very involved in its management. It may be necessary to resolve these existing public engagement issues before the public can become involved in any meaningful way in the desired long-term, integrated and holistic vision for the coast, including and beyond FRM.

\section{Introduction}

\section{Background}

The management of coastal flooding is continually evolving to address a changing society and a changing risk (Penning-Rowsell and Johnson 2015). In recent decades in England, there has been a shift from solely focusing on reducing the severity and frequency of flood events, toward managing 
coastal flooding through flood risk management (FRM) (Hall, Sayers, and Dawson 2005; Butler and Pidgeon 2011). FRM aims not only to reduce the occurrences of floods through engineered sea walls and other structures, but also to on reduce the risks that floods pose to society. The status quo is thus no longer necessarily to "defend". In Shoreline Management Plans (SMPs), for example, "holding the line" and "advancing the line" are only half of the options: alternatives include "managed realignment" and "no active intervention" (Defra 2006). This study focuses specifically on coastal flood risk strategic planning, protection and prevention, not erosion risk nor emergency response, and examines the expected roles and practice of policy for insurance, public and private engineering, and planning, in both short and long-term coastal flood adaptation.

Concurrently, the national government is placing increasing FRM responsibilities on a local level, both upon authorities and organisations as well as upon individuals (Begg et al. 2017). This raises questions as to the characteristics of households that affect their awareness and response to flood risk (Bubeck et al. 2017; Koerth et al. 2017). While there is this trend of devolving FRM responsibilities to a local even household - level, whether this devolution of responsibility is being accompanied by a devolution of power is dubious (Begg et al. 2015; Begg 2018).

It is not known what expectations stakeholders active locally - including authorities, public bodies, landowners and insurers - have of the public in coastal FRM. The aim of this paper is to use two case studies to analyse the challenges of stakeholders implementing FRM prevention, protection and preparedness policy locally, and their expectations of the public regarding coastal flood risk. We analyse the challenges from engineering, planning and insurance perspectives, through a thematic analysis of semi-structured interviews in two English regions.

\section{Outline of This Paper}

This paper uses two English case studies to explore challenges to implementing national FRM policy relevant to the coasts locally (but with wider implications), especially regarding local stakeholders' expectations of the public. This may provide insights for coastal managers in other developed countries managing coastal flood risk across coastlines with both dense urban and sparser rural populations. Following an explanation of the case methods and a description of the selected sites, the process of the semi-structured interviews and thematic analysis of the data is outlined.

The discussion is split into three parts. Firstly, the question of who the public is and what is broadly expected of them is explored. This is followed by an examination of responsibilities and financial duties that stakeholders expected of the public. Finally, the inclusion and exclusion of the public in adaptation conversations is described in further detail.

\section{Methods}

Data was collected through semi-structured interviews conducted primarily in two English coastal areas - in the northwest and the south - and coded using theory and data-driven codes for thematic analysis.

\section{Case study areas}

To record stakeholders' expectations of the public in coastal FRM, a case study method was used. Case-based research allows for the exploitation of cases of FRM being implemented in more than one context, and the subsequent identification of features of value for further analysis, either in the same case or beyond the original case studies (Morgan 2018). The two cases were selected from a shortlist of English coastal areas (as they share the same national legislation and public bodies), which have a variety of coastal flood risk (urban/rural, diverse industries, natural and engineered coastlines, socioeconomic characteristics), and that are recorded as having experienced a coastal flood since 1916 (using the Surgewatch database) (Haigh et al. 2017).

The North West case area covered the Lancashire and Cumbrian coastlines (Figure 1a). This area includes both dense, urban conglomerations such as Southport, Blackpool and Fleetwood, as well as agricultural and rural communities on the Fylde Peninsula. There is a contrast between the ongoing significant investment for coastal defences on the Fylde Peninsula (in 2015-2021, £120 million will be invested on coastal protection schemes) and the Cumbrian coastline, where a coastal strategy is still currently being produced (2017-2019). The studied coastline encompasses multiple local authorities but only one SMP (North West SMP, Great Orme to Scotland), thus allowing for analysis of localised differences in policy practices, as well as commonalities across the region. 
In the South case area, parts of the Hampshire, Dorset and Isle of Wight coastlines were studied (Figure 1b). Similarly, this area encompasses significant settlements as well as more sparsely populated coast. For much of the coastline there are ongoing beach management works, such as the beach replenishment at Bournemouth, and the maintenance and replacement of groynes (Johns et al. 2010). Furthermore, this case covers three SMP coastlines (Selsey Bill to Hurst Spit, Isle of Wight, Hurst Spit to Durslton Head), granting opportunity to compare across plans.

Both cases have a legacy of coastal flood defences, such as the seawalls on the Blackpool coast and groynes at Bournemouth, as well as more rural stretches of coastline with a legacy but less contemporary spending, such as the north of the Fylde Peninsula and part of the New Forest coastline. Thus, it was possible to compare responses within case areas, between stakeholder groups, and across case areas experiencing locally different environmental, social and economic conditions. Using the North West and South case areas, responses can be compared within case areas, between stakeholder groups, and across case areas experiencing locally different environmental, social and economic conditions.

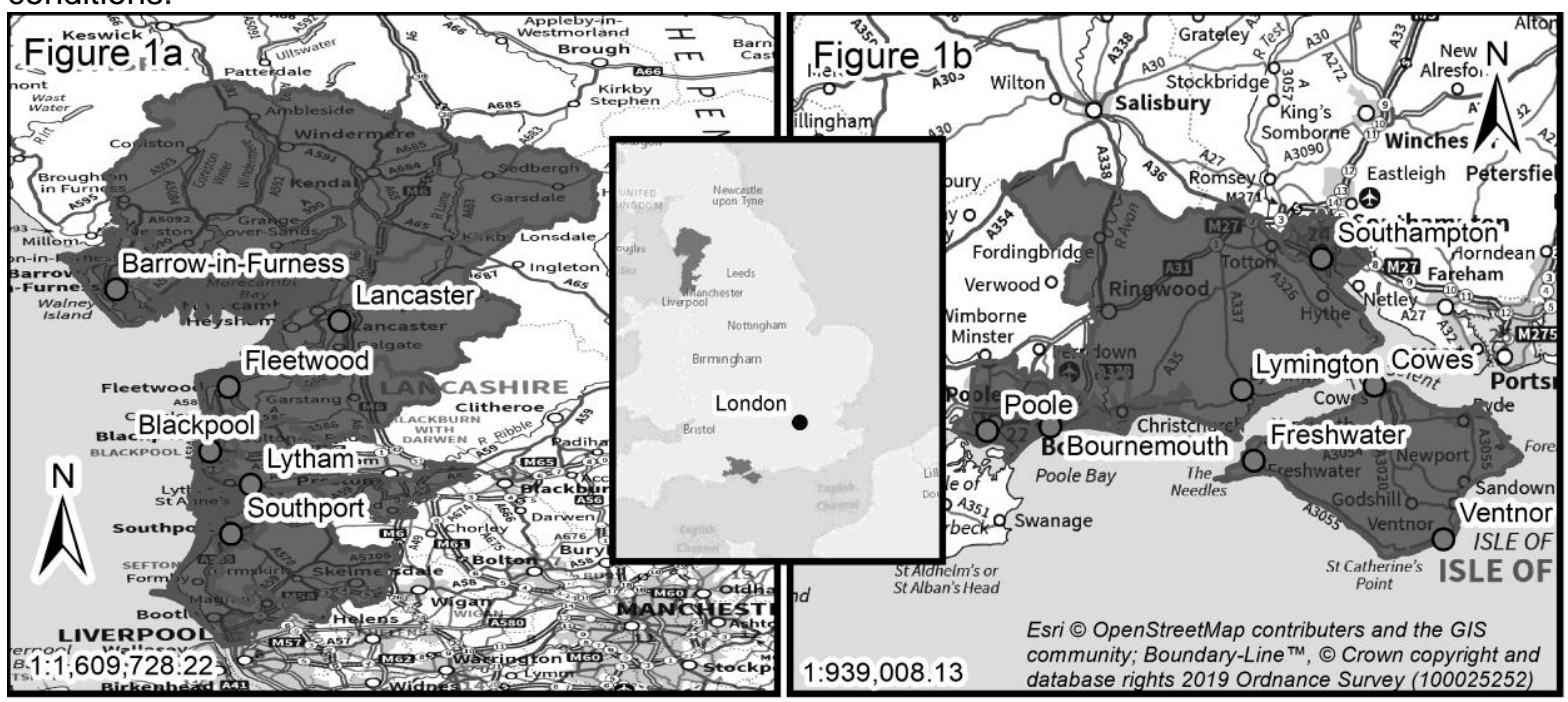

Figure 1: Location of case study areas, England

\section{Primary interview data collection}

Primary data was collected by the first author through semi-structured interviews with 45 stakeholders in the two case study areas, from May-October 2018. The sampling method was purposeful, with interviewees being selected per their anticipated richness in contribution to the research aim (Gentles et al. 2015). Stakeholder analysis was used to identify potential interviewees, whereby stakeholders are selected according to their influence and importance to the specific project or process (Prell et al. 2009). The primary targeted stakeholders for interviewing were those who have some or significant influence in coastal FRM in either of the case areas, or for whom flood risk is an important factor to consider within their responsibilities and interests, as defined in Figure 2. Snowballing also took place, where stakeholders recommended by interviewees were invited to take part in this research.

Stakeholder groups who were interviewed are outlined in Figure $2(n=45)$, with interviewing lasting 3090 minutes. Questions were asked regarding the costs, timing, power, responsibility, acceptability, equity, and effectiveness of FRM (Tompkins, Few and Brown 2008). Questions were generally openended, and interviewees were encouraged to interpret the questions and respond as they understood them. Response rates are shown in Table 1. 


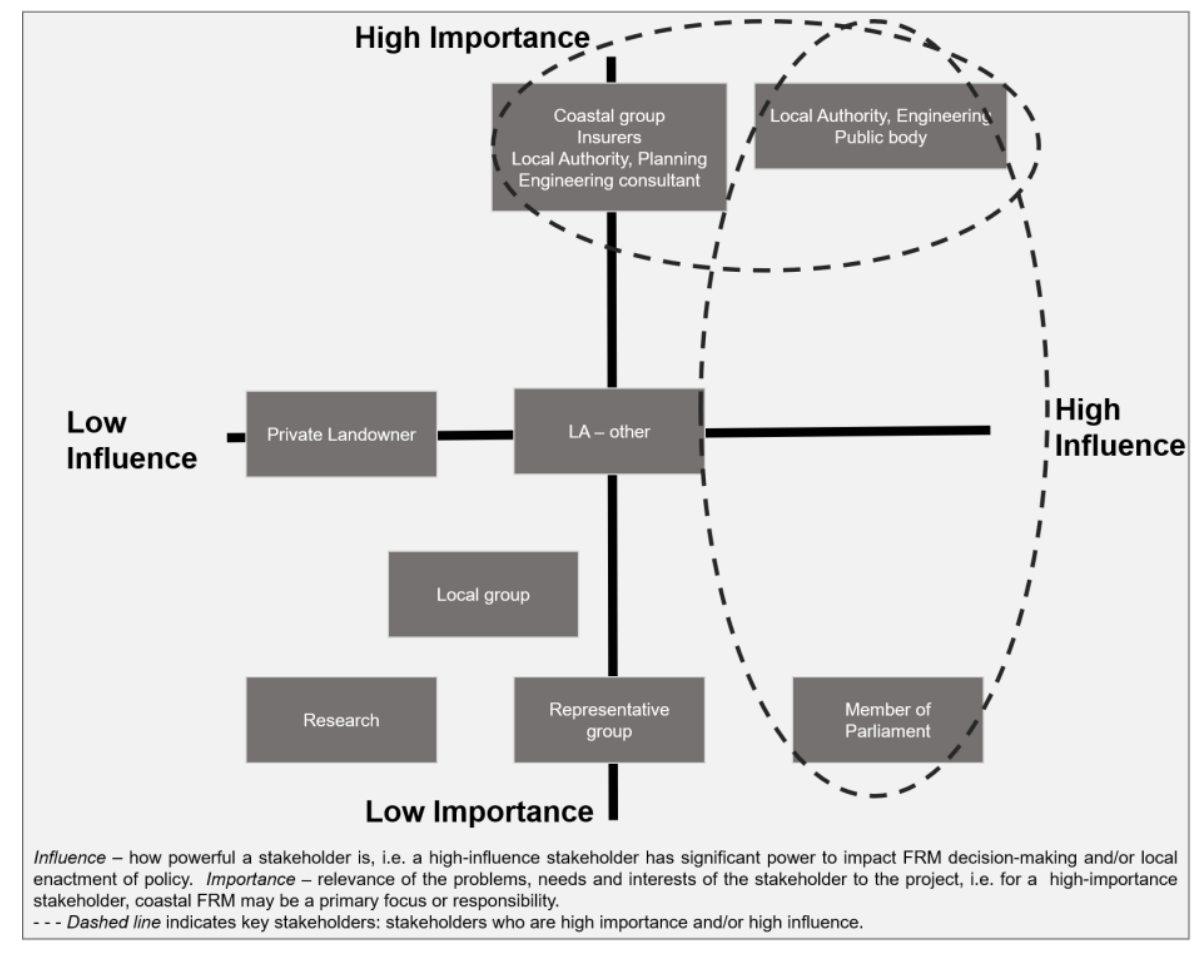

Figure 2: Stakeholder analysis for interview sampling

Table 1: Response rates according to case area

\begin{tabular}{|l|l|l|l|l|}
\hline & National & North West & South & $\begin{array}{l}\text { TOTAL } \\
\text { (response rate all/total) }\end{array}$ \\
\hline No response / declined & $52(82.5 \%)$ & $78(82.1 \%)$ & $90(84.1 \%)$ & $220(83.0 \%)$ \\
\hline Interviewed & $11(17.5 \%)$ & $17(17.9 \%)$ & $17(15.9 \%)$ & $45(17.0 \%)$ \\
\hline TOTAL & 63 & 95 & 107 & 265 \\
\hline
\end{tabular}

\section{Thematic analysis of coded interview data}

The interview data was analysed through thematic analysis: an iterative process of theory- and databased coding, following the stages of coding and analysis laid out in Fereday and Muir-Cochrane (2006) and Nowell et al. (2017). Although thematic analysis is not oft-used in the coastal engineering discipline, it brings the benefit of understanding not just what stakeholders in coastal FRM are doing, but why what reasoning and logic underlies local FRM actions. Previous examples of thematic analysis with relation to coastal engineering include an evaluation of public perceptions to engineering for coastal flood and erosion risk mitigation (Touili et al. 2014), and the development of a Decision Support System for communicating coastal risk between scientists, policy-makers, and the public (Kane et al. 2014).

First, a code manual of themes (description of a concept or phenomenon), categories (unit of organisation encompassing multiple codes) and codes was constructed (tags assigning units of meaning to data) (Saldaña 2008; DeCuir-Gunby et al. 2011). This code manual was based on (a) the themes on which the interview questions were based - costs, timing, power, responsibility, acceptability, equity, and effectiveness of FRM (as defined by Tompkins, Few and Brown 2008), and; (b) a literature review on the challenges to integrating spatial planning, engineering and insurance as coastal FRM in England. This code manual was revised after its application was tested with colleagues, and following the first round of coding (which used the code manual as well as data-driven codes) (Saldana 2008). From the second coding cycle, a final series of themes, categories and codes were established.

\section{Discussion of results}

Five key themes were identified following the second round of coding, summarised as: (1) public awareness and engagement, (2) resourcing and empowerment, (3) adaptable and holistic future coastal vision, (4) integrated spatial planning, and (5) relationship with the insurance industry. In this paper, we focus on stakeholders' views of public awareness and engagement in coastal FRM, exploring this 
through the themes of resourcing and empowerment, and a future vision; themes 4-5 may be explored in later papers.

After introducing the variation in interviewees' conception of "the public", the discussion is broken down by analysing, first, key stakeholders' expectations of the role and responsibility of the public in resourcing (their own) FRM in the case study areas and, second, the challenges in incorporating the public into the process of developing a future vision for the coast.

\section{Who are the public and what should they do?}

The public, stakeholders argue in both the North West and the South cases, need to be educated and engaged in coastal FRM; yet there is little consensus on who needs to be engaged, and what the level of necessary engagement is.

There was significant variation in how interviewees described the public, including not only landowners but also communities and families [Table 2, quotes 1-3; Table 3, 3-4]. Similarly, respondents left largely undefined what the goals of such engagement might be. The goals of engagement ranged from educating to jointly developing a future vision for the coast [Table 2, 2-3]. The EA uses a wide variety of public engagement approaches, including a flood warning service with 1.4 million people signed up, Regional Flood and Coastal Committees to work with coastal groups and lead local flood authorities, and regular campaigns to raise awareness of households in flood risk areas (e.g. 2017-2018 campaign 'Prepare, Act, Survive'). Nonetheless, the EA's top-down approach in communicating flood risk has been previously highlighted (Nye et al. 2011) and these results suggest the "educating" focus perseveres in the two case areas, despite efforts to do more.

Despite the perceived lack of engagement of the public currently in the case areas, multiple stakeholders suggested the public should have a greater role in coastal FRM. Knowing what the public think as to be able to negotiate a shared responsibility for flood risk, and developing participation to be inclusive of individuals with different visions of flood management regardless of their knowledge levels has been previously suggested as more inclusive and effective engagement practices (Birkholz et al. 2014; Smith and Bond 2018). Insurance can also play a role in creating two-way engagement in FRM, through encouraging the implementation of resilience and resistance measures and rewarding such behaviour through premium deductions or variations thereof (Oakley 2018). These results suggest the need for greater prioritisation of engaging the public at the local level, increasing awareness and educating the public on their role in coastal flood risk management.

Table 2: Who are the public and what should they do?

\begin{tabular}{|l|l|}
\hline $\begin{array}{l}\text { Category } \\
\text { Explanation }\end{array}$ & Examples \\
\hline $\begin{array}{l}\text { Public engagement } \\
\text { The need for further } \\
\text { engagement of the } \\
\text { "public" regarding } \\
\text { coastal flood risk and } \\
\text { its management }\end{array}$ & $\begin{array}{l}\text { (1) "Communication with the public, and who's responsible for what." - } \\
\text { Local Authority Engineer, South } \\
\text { happening, and what the potential consequences are in the future." } \\
\text { Local Authority, North West } \\
\text { (3) "You need a broader involvement but it is the involvement of people } \\
\text { in creating the vision. That applies to Communities as well. Whatever a } \\
\text { community is... And you're actually asking them to create a vision." } \\
\text { Engineering Consultant, England }\end{array}$ \\
\hline
\end{tabular}

\section{The public as an FRM financer}

This greater role for the public in coastal FRM could stem, for instance, from assisting in resourcing it. Although government financing is very much focused on defending households, there were suggestions that householders can have greater responsibility for risk and should therefore fund more of their own FRM.

\section{Government funding for households}

Government funding for coastal FRM prioritises reducing risk to households; yet this does not mean all communities will be defended indefinitely into the future, nor the commercial assets that form an integral part of them. The Outcome Measures for Partnership Funding acknowledge management targets other 
than reducing risk to households, but a priority and primary driver of funding calculations is households moved to a lower risk category (Defra 2011; Defra and Cabinet Office 2016). This prioritisation was underlined by multiple stakeholders in both case areas [Table 3, 1]. However, in multiple towns and villages within the case areas it is businesses and community assets that occupy the floodplain. These contribute less toward funding scores [Table 3,1$]$, despite providing a recognised variety of benefits to an area, including economic, health, social, and cultural gains (for recent policy and legislation on assets of community value, see The Assets of Community Value (England) Regulations 2012).

Another potential pitfall of having a funding model driven by the number of households with reduced flood risk is that it limits future visions for the coast to being akin to past coastal engineering ambitions: defend. It is sensible to plan for what is fundable and realisable, but with current funding for non-holdthe-line options being minimal, respondents suggest this does not encourage relocation, realignment, or resilience projects. Without the funding to implement alternative FRM approaches, what incentive is there for Local Authorities to engage in non-defence options [Table 3, 2]? The Committee on Climate Change's most recent coastal adaptation report suggests legally binding and funded adaptation plans are one way to resolve this (Russell et al. 2018).

\section{Table 3: Households and funding FRM}

\begin{tabular}{|c|c|}
\hline $\begin{array}{l}\text { Category } \\
\text { Explanation }\end{array}$ & Examples \\
\hline $\begin{array}{l}\text { Household-focused } \\
\text { funding } \\
\text { The number of } \\
\text { households } \\
\text { protected is a key } \\
\text { figure in Defra's } \\
\text { funding calculations } \\
\text { for FRM investment. }\end{array}$ & $\begin{array}{l}\text { (1) "The scoring mechanism is based on impact to residential properties } \\
\text { only. Commercial properties don't actually have a score in their own } \\
\text { right... there is no way of counting commercial properties to stack up the } \\
\text { scores." - Local Authority Engineer, South } \\
\text { (2) "There is no established funding for how you go about not defending } \\
\text { somewhere." - Consultant Engineer, England }\end{array}$ \\
\hline $\begin{array}{l}\text { Responsibility for } \\
\text { coastal FRM } \\
\text { People need to take } \\
\text { greater responsibility } \\
\text { for coastal flood risk, } \\
\text { but might be } \\
\text { unaware that the } \\
\text { responsibility already } \\
\text { exists. }\end{array}$ & $\begin{array}{l}\text { (3) "A landowner may not be aware that an asset is actually theirs, they } \\
\text { own it because it's on their land ... it's there under permissive powers } \\
\text { and it can be taken away or maintenance stopped at any point... it's the } \\
\text { ongoing engagement issue." - Engineering Consultant, England } \\
\text { (4) "Encouraging people, businesses, families, communities to take } \\
\text { greater responsibility for their own resilience." - Coastal Group, South } \\
\text { (5) "For the coast, it is going to be convincing people the need to adapt." } \\
\text { - Engineering Consultant, England } \\
\text { (6) "Come } 2040 \text {, in theory we should be in a position where a lot more } \\
\text { properties are in a lot better position in terms of flood risk. Even if they } \\
\text { are at risk of flood, they've taken measures to protect themselves to } \\
\text { reduce the impact of flood damage." - Insurer, England }\end{array}$ \\
\hline $\begin{array}{l}\text { Individual financing } \\
\text { People need to pay } \\
\text { (more) for their own } \\
\text { FRM }\end{array}$ & $\begin{array}{l}\text { (7) "There's lots of new developments on the coastal fringe, and they're } \\
\text { all building in their own resilience, and therefore assisting people that } \\
\text { live behind them, from the frontage. It could be individual house-owners } \\
\text { as well as Government or Local Authority." - Local Authority Engineer, } \\
\text { South } \\
\text { (8) "Cases of } 2014 \ldots \text {... I'm aware that some private asset owners were } \\
\text { trying to get Government money, and there was a lot of going backward } \\
\text { and forward trying to get money for it out of Government. The eventual } \\
\text { pushback was 'no it's your asset you pay for it,' so private money had to } \\
\text { be found." - Engineering Consultant, England } \\
\text { (9) "Some communities can no longer be defended... they have to } \\
\text { recognise that they're living on the wrong side of the defences and if } \\
\text { they want to continue, they have to find other means of managing the } \\
\text { flood risk, whether that be in terms of resilience or localised defences of } \\
\text { their own." - Engineering Consultant, England }\end{array}$ \\
\hline
\end{tabular}

Individual risk responsibilities

Stakeholders by and large expressed the view that individuals, people and communities should be taking greater responsibility for their own flood risk, but that in many cases these groups may be unaware of 
the risk or already existent responsibilities. For example, there were multiple references to landowners unaware of their flood defence maintenance responsibilities [Table 3,3]. The language of the responsibility expectations differed from the need to "convince people" to "encouraging" [Table 3, 4-5]. There were also hopes that the insurance industry could offer incentives to encourage behaviours such as uptake of household flood resilience measures [Table 3,6]. Despite this desire for a coastal FRM which further involves the public, local respondents were unsure on how this goal might be achieved. Previous research into this shift of responsibilities suggests that whilst individuals are indeed expected to take on an increased responsibility for flood risk, the traditional power-holders in FRM (i.e. especially national government stakeholders) remain the same (Penning-Rowsell and Johnson 2015; Begg 2018). Increased individual responsibility could be encouraged by incentivising and resourcing further flood action groups (Dittrich et al. 2016), as well as resourcing and supporting capacity-development, and traditional stakeholders being open to the alternative FRM discourses and visions of the public (Smith and Bond 2018).

\section{Individual FRM funding responsibilities}

Individuals, notably those "living on the wrong side of defences", "can no longer be defended", and "private asset owners" are not only being expected by stakeholders in the North West and South case areas to take up attributed or increasing responsibilities for coastal FRM, but also to help finance it [Table 3, 8-9]. Despite landowners and those behind defences being encouraged make funding contributions, Benson et al. (2016) suggest government maintains control of the structure of FRM processes, such as through the prioritisation of specific flood defence objectives. This may mean, for example, that in areas where the SMP or management strategy suggests managed realignment or no active intervention in flood defences, landowners may be mandated not to physically intervene in ongoing natural processes at all.

Financing of coastal FRM in England has become somewhat more localised in recent years through Partnership Funding, whereby stakeholders are encouraged to contribute toward the project to make up any shortfall (or simply to assist) in the Defra contribution [Table 3, 7]. Partnership Funding may empower the additional contributors to have greater influence in scheme development, and enable schemes to go ahead that previously would not have acquired sufficient funding (Defra 2011). However, shifting the funding burden toward local, even household, contributions toward coastal FRM should be pursued with caution.

Recent analysis has shown flood risks to be higher in socially vulnerable communities, especially in coastal areas and economically struggling cities (Sayers, Penning-Rowsell and Horritt 2018). Payment rates for protecting households in deprived areas are higher, but Partnership Funding does not account for the reduced spending capacity of economically struggling towns and households, and possibly reduced social networks and social adaptation capacities of coastal communities (Lindley et al. 2011). Responsibility and power may have been somewhat devolved in England in coastal FRM and planning, but with many coastal towns experiencing disadvantage, isolation and decline (Select Committee on Regenerating Seaside Towns and Communities 2019), their resourcing to act on such devolution is uncertain.

\section{The public as part of adaptation conversations}

Multiple stakeholders thought that the public needed to be part of a future vision and discussions about potential relocation, yet stakeholders also suggested that in their local area public awareness of coastal flood risk remains low, raising concern over how they can be fairly engaged in adaptation and relocation debates.

\section{Relocation}

The public needs to be more aware of flood risk with regard to possible contemporary or future relocation of houses and communities. However, there remains little to no government policy to support relocation as a coastal FRM option. By 2030,550km of coastline needs to be realigned (from a baseline of 2000) to meet SMP targets; this would require a five-fold increase in the managed realignment rate from 2000 2012 (Russell et al. 2018). While there is, then, a clear policy interest in retreat as a management option, there appears to be some form of implementation shortfall locally in the two case areas [Table 4, 2]. In some respondents' experiences, there is little to no funding to support and accompany debate about relocation and enable its actualisation [Table 4, 3], suggesting that although the policy focus in SMPs may be beyond seeing maintaining the current line of defence as the only policy option, defence options are still those most favoured by contemporary funding models. 
To meet the significant 'managed realignment' targets in SMPs may require relocation of households. However, communities in the case areas of this study currently remain largely absent from discussions regarding possible future relocation; by and large because those discussions are not being had at all [Table 4, 1]. Interestingly, stakeholders in both case study areas discussed issues around public engagement and relocation, despite the North West case area having significantly more policy units in which the second-epoch SMP policy moves from hold-the-line to managed-realignment; this suggests key local stakeholders are potentially operating in coastal adaptation challenges and discourses beyond their local boundaries. The case of Fairbourne, Wales, has become a noted example of the tensions and complexities of an SMP planning for realignment in an area with household residences, and of enacting that future adaptation plan with the engagement of the local community. Here, the SMP planned for Managed Realignment (second epoch) and No Active Intervention (third epoch) (Guthrie and Clipsham 2011), but for the village this had immediate ramifications including falling house prices and reduced mortgage access (HC Deb 7 July 2015). Even then, facilitating public debate about managed realignment is only one step toward what one might call "successful" or "effective" stakeholder engagement (Thaler and Levin-Keitel 2016).

Table 4: The public and relocation/adaptation conversations

\begin{tabular}{|l|l|}
\hline $\begin{array}{l}\text { Category } \\
\text { Explanation }\end{array}$ & Examples \\
\hline $\begin{array}{l}\text { Relocation } \\
\text { Public debate } \\
\text { should be } \\
\text { increased on the } \\
\text { possibility and } \\
\text { potential need for } \\
\text { future relocation } \\
\text { of properties and } \\
\text { communities. }\end{array}$ & $\begin{array}{l}\text { (1) is not feasible in terms of return on public investment to protect certain } \\
\text { communities from erosion, rising sea levels, flood risk associated with various } \\
\text { factors. That community or part of it will have to be abandoned and rebuilt on a } \\
\text { different site on higher ground... I don't yet think that there's been that public } \\
\text { debate." - Coastal Group, South } \\
\text { (2) "We're going to embark on how we are going to be in a position in 40 years' } \\
\text { time that we no longer need to defend. And there's no compensation or } \\
\text { anything like that ... How you go about doing that, there is no real Government } \\
\text { policy that allows you to do this?" - Engineering Consultant, England } \\
\text { (3) "Managed realignment for tidal flood risk areas is a question of moving } \\
\text { back... There's not a very good funding mechanism currently to pay for that, } \\
\text { other than to create intertidal habitat, which isn't the answer everywhere. How } \\
\text { can we set up a fund where 'Holding the Line' is often the least appropriate } \\
\text { solution but it's the only one that's fully funded?" - Public Body, South }\end{array}$ \\
\hline $\begin{array}{l}\text { Adaptation } \\
\text { People should be } \\
\text { thinking longer- } \\
\text { term and } \\
\text { holistically about } \\
\text { coastal FRM, } \\
\text { including } \\
\text { communities in it. }\end{array}$ & $\begin{array}{l}\text { (4) "We're looking at a view which isn't just the next 10, 20 years, it's a long- } \\
\text { term view. We should be able to protect and make those coastal communities } \\
\text { really vibrant. That's the big challenge." - Local Authority Engineer, North West } \\
\text { (5) "The adaptation discussions require engagement, long-term engagement } \\
\text { by probably someone local on the ground who can develop relationships. } \\
\text { These people aren't there. They don't have the time and resources to invest in } \\
\text { that level of engagement." - Engineering Consultant, England }\end{array}$ \\
\hline
\end{tabular}

\section{Adaptation}

Despite the call for more robust adaptation plans to future sea level rise and coastal change (Russell et al. 2018), interviewees described a lack of long-term engagement of the public in developing any such plans in the case study areas [Table 4,5]. SMPs and strategies such as the long-term multi-pathway Thames Estuary 2100 (Environment Agency 2012) suggest that there is political appetite for coastal FRM focussed on a time beyond a few decades in at least some areas. However, stakeholders considered maintaining long-term engagement of communities in future visions as challenging [Table 4, 4]. While there is increasing research and national policy on long-term adaptation on the coast, stakeholders suggest this process is only just beginning locally. Furthermore, multiple stakeholders concurred that the public needed to take on greater responsibility for their risk, resilience and adaptation [Table 3, 4-6]. These views are admirable in granting autonomy and power to individuals, but there is currently little funding available locally for long-term public engagement plans, staff and implementation to support individuals taking on this responsibility [Table 4, 5] (Begg et al. 2015). 


\section{Conclusion}

Local Authorities and other FRM stakeholders more widely in the two case study areas are expecting individuals and communities to be at the very least more aware of their flood risk, if not also more responsible and more involved in its management (Begg et al. 2017; Begg 2018). There is, however, a disjuncture between (1) the ambition for increased public debate on a future vision for the coast and expectations of greater public involvement in coastal FRM, and (2) a public who is perceived to be not very aware of their coastal flood risk, do not feel very responsible for it, and are currently not very involved in its management. There remains a gap between national policy ambitions for public participation, and the low levels described locally in the North-West and South case studies. The authors suggest this indicates the need for resourced, ongoing engagement in coastal FRM and adaptation, not solely SMP, strategy or scheme-based engagement; but a process that is sufficiently resourced to develop social adaptive capacity in socially vulnerable areas, and with traditional key stakeholders being open to FRM visions and discourses contrary to those currently dominant in policy and practice. This finding may of particular interest in relation to the revision of the Flood and Coastal Erosion Risk Strategy for England.

The results from this paper support at a local scale in two areas the findings of the Committee on Climate Change that England is still not prepared for the longer-term implications of climate change, especially regarding adaptation and possible retreat (managed realignment) of coastlines (Russell et al, 2018). Despite the increasing message that the status quo cannot be continued defence for all the English coast where it has been thus to date, the public in the North West and South case areas continues to miss out on hearing that message, and therefore unsurprisingly continues to expect a widespread "hold the line" approach. This is a major barrier to delivering the vision of SMPs and wider FRM. Next steps include further investigation of the level of responsibility that local stakeholders expect of households for coastal flood risk, as well as what is affecting (hindering) households' own perceptions of their responsibility for flood risk. This shows an important role for the type of analysis highlighted in this paper to inform and support improved coastal FRM.

\section{References}

Begg, C. (2018) Power, responsibility and justice: a review of local stakeholder participation in European flood risk management. Local Environment. 23 (4), 383-397.

Begg, C., Callsen, I., Kuhlicke, C. \& Kelman, I. (2017) The Role of Local Stakeholder Participation in Flood Defence Decisions in the UK and Germany. Journal of Flood Risk Management.

Begg, C., Walker, G. \& Kuhlicke, C. (2015) Localism and flood risk management in England: the creation of new inequalities? Environment and Planning C: Government and Policy. 33 (4), 685-702.

Benson, D., Lorenzoni, I. \& Cook, H. (2016) Evaluating social learning in England flood risk management: An 'individual-community interaction' perspective. Environmental Science \& Policy. 55326-334.

Birkholz, S., Muro, M., Jeffrey, P. \& Smith, H.M. (2014) Rethinking the relationship between flood risk perception and flood management. Science of The Total Environment. 47812-20.

Bubeck, P., Wouter Botzen, W.J., Laudan, J., Aerts, J.C.J.H. \& Thieken, A.H. (2017) Insights into FloodCoping Appraisals of Protection Motivation Theory: Empirical Evidence from Germany and France: Insights into Flood-Coping Appraisals of Protection Motivation Theory. Risk Analysis.

Butler, C. \& Pidgeon, N. (2011) From 'Flood Defence' to 'Flood Risk Management': Exploring Governance, Responsibility, and Blame. Environment and Planning C: Government and Policy. 29 (3), 533-547.

DeCuir-Gunby, J.T., Marshall, P.L. \& McCulloch, A.W. (2011) Developing and Using a Codebook for the Analysis of Interview Data: An Example from a Professional Development Research Project. Field Methods. 23 (2), 136-155.

Defra (2011) Flood and Coastal Resilience Partnership Funding.

Defra (2006) Shoreline management plan guidance Volume 1: Guidance.

Defra \& Cabinet Office (2016) National Flood Resilience Review.

Dittrich, R., Wreford, A., Butler, A. \& Moran, D. (2016) The impact of flood action groups on the uptake of flood management measures. Climatic Change. 138 (3-4), 471-489.

Environment Agency (EA) (2012) TE2100 Plan: Managing flood risk through London and the Thames estuary. 
Fereday, J. \& Muir-Cochrane, E. (2006) Demonstrating Rigor Using Thematic Analysis: A Hybrid Approach of Inductive and Deductive Coding and Theme Development. International Journal of Qualitative Methods. 5 (1), 80-92.

Gentles, S., Charles, C., Ploeg, J. \& McKibbon, K. (2015) Sampling in Qualitative Research: Insights from an Overview of the Methods Literature. The Qualitative Report. 20 (11), 1772-1789.

Guthrie, G. \& Clipsham, V. (2011) West of Wales Shoreline Management Plan 2 - Section 6 Summary and Comparison of Policy.

Haigh, I.D., Ozsoy, O., Wadey, M.P., Nicholls, R.J., Gallop, S.L., Wahl, T. \& Brown, J.M. (2017) An improved database of coastal flooding in the United Kingdom from 1915 to 2016. Scientific Data. 4170100.

Hall, J.W., Sayers, P.B. \& Dawson, R.J. (2005) National-scale Assessment of Current and Future Flood Risk in England and Wales. Natural Hazards. 36147-164.

HC Deb, 7 July 2015. Coastal Flood Risk. Vol. 598, col. 14WH.

Johns, D., Smalls, M. \& Maslen, S. (2010) Case Study Report 10: Bournemouth, Poole Bay \& Swanage Beach Replenishment.

Kane, I.O., Vanderlinden, J.-P., Baztan, J., Touili, N. \& Claus, S. (2014) Communicating risk through a DSS: A coastal risk centred empirical analysis. Coastal Engineering. 87240-248.

Koerth, J., Vafeidis, A.T. \& Hinkel, J. (2017) Household-Level Coastal Adaptation and Its Drivers: A Systematic Case Study Review: Household-Level Coastal Adaptation and Its Drivers. Risk Analysis. 37 (4), 629-646.

Lindley, S., O'Neill, J., Kandeh, J., Lawson, N., Christian, R. \& O'Neill, M. (2011) Climate change, justice and vulnerability. Joseph Rowntree Foundation.

Morgan, M.S. (2018) Exemplification and the use-values of cases and case studies. Studies in History and Philosophy of Science Part A. In press.

Nowell, L.S., Norris, J.M., White, D.E. \& Moules, N.J. (2017) Thematic Analysis: Striving to Meet the Trustworthiness Criteria. International Journal of Qualitative Methods. 16 (1), 160940691773384.

Nye, M., Tapsell, S. \& Twigger-Ross, C. (2011) New social directions in UK flood risk management: moving towards flood risk citizenship?: Flood risk citizenship. Journal of Flood Risk Management. 4 (4), 288-297.

Oakley, M. (2018) Incentivising household action on flooding. Social Market Foundation. p.1-82.

Penning-Rowsell, E.C. \& Johnson, C. (2015) The ebb and flow of power: British flood risk management and the politics of scale. Geoforum. 62131-142.

Prell, C., Hubacek, K. \& Reed, M. (2009) Stakeholder Analysis and Social Network Analysis in Natural Resource Management. Society \& Natural Resources. 22 (6), 501-518.

Russell, A., Brown, K., Stark, C., Style, D., Barrett, J., Gault, A., Millar, R., Holmes, G. \& Freeman, B. (2018) Managing the coast in a changing climate. Committee on Climate Change.

Saldaña, J. (2016) The coding manual for qualitative researchers. 3E [Third edition]. Los Angeles; London: SAGE.

Sayers, P., Penning-Rowsell, E.C. \& Horritt, M. (2018) Flood vulnerability, risk, and social disadvantage: current and future patterns in the UK. Regional Environmental Change. 18 (2), 339-352.

Select Committee on Regenerating Seaside Towns and Communities (2019) The future of seaside towns.

Smith, J. \& Bond, A. (2018) Delivering more inclusive public participation in coastal flood management: A case study in Suffolk, UK. Ocean \& Coastal Management. 161147-155.

Thaler, T. \& Levin-Keitel, M. (2016) Multi-level stakeholder engagement in flood risk management-A question of roles and power: Lessons from England. Environmental Science \& Policy. 55, 292 301.

The Assets of Community Value (England) Regulations 2012, 2012 No. 2421.

Tompkins, E.L., Few, R. \& Brown, K. (2008) Scenario-based stakeholder engagement: Incorporating stakeholders preferences into coastal planning for climate change. Journal of Environmental Management. 88 (4), 1580-1592.

Touili, N., Baztan, J., Vanderlinden, J.-P., Kane, I.O., Diaz-Simal, P. \& Pietrantoni, L. (2014) Public perception of engineering-based coastal flooding and erosion risk mitigation options: Lessons from three European coastal settings. Coastal Engineering. 87205-209. 